\title{
The Serology of Chronic Hepatitis B Infection Revisited
}

Toshiyuki Maruyama, * Alan McLachlan, ${ }^{*}$ Shiro lino, ${ }^{5}$ Kazuhiko Koike, ${ }^{5}$ Kiyoshi Kurokawa, ${ }^{5}$ and David R. Milich *

${ }^{*}$ Department of Molecular Biology, and ${ }^{\ddagger}$ Department of Molecular and Experimental Medicine, The Scripps Research Institute, La Jolla, California 92037; and ${ }^{\S}$ The First Department of Internal Medicine, Faculty of Medicine, University of Tokyo, Tokyo 113, Japan

\begin{abstract}
The serology of chronic hepatitis B infection has been established through the use of commercial immunoassays to measure the structural antigens of the hepatitis $B$ virus and their respective antibodies in serum. However, the commercial assays have not been designed to detect serum antibodies in the presence of an excess of circulating antigens. A series of serum samples from $200 \mathrm{HBeAg}$-positive, chronically infected hepatitis B patients with varying degrees of liver disease were analyzed using novel immunoassays designed to detect antibodies in the presence of circulating viral antigens. All patients, regardless of their liver disease, were seronegative for antibodies specific for the envelope antigens or the secreted nucleoprotein antigen (HBeAg) when the commercial assays were used. In contrast, virtually all chronically infected patients with liver disease and $\sim 50 \%$ of patients without liver disease demonstrated anti-HBe and anti-envelope antibodies when sera were tested in the more sensitive immunoassays. Furthermore, asymptomatic patients could be serologically distinguished from symptomatic patients based on antibody fine specificity, titer, and IgG subclass. This study revealed that the majority of chronically infected hepatitis $B$ patients produce a variety of antibodies for many years, and are not immunologically unresponsive, as suggested by the current assays. (J. Clin. Invest. 1993. 91:2586-2595.) Key words: hepatitis B virus • chronic infection • serology $\bullet$ immune complex
\end{abstract}

\section{Introduction}

More than 250 million people throughout the world are estimated to be chronically infected with the hepatitis $B$ virus (HBV), ${ }^{1}$ which is the primary source of chronic hepatitis, liver cirrhosis ( $\mathrm{LC}$ ), and hepatocellular carcinoma in endemic areas (1). Chronic hepatitis B ( CH-B) infection is represented by a spectrum of disease entities classified as: chronic active hepatitis $(\mathrm{CAH})$, chronic persistent hepatitis $(\mathrm{CPH})$, and the asymp-

Address correspondence to Dr. David R. Milich, Department of Molecular Biology, The Scripps Research Institute, La Jolla, CA 92037.

Received for publication 24 August 1992 and in revised form 21 January 1993.

1. Abbreviations used in this paper: ALT, alanine aminotransferase; ASC, the asymptomatic carrier state; $\mathrm{CAH}$, chronic active hepatitis; $\mathrm{CH}-\mathrm{B}$, chronic hepatitis $\mathrm{B}$; $\mathrm{CPH}$, chronic persistent hepatitis; EIA, enzyme immunoassay; HBV, hepatitis B virus; IC, immune complex; LC, liver cirrhosis.

J. Clin. Invest.

(c) The American Society for Clinical Investigation, Inc.

$0021-9738 / 93 / 06 / 2586 / 10 \$ 2.00$

Volume 91, June 1993, 2586-2595 tomatic carrier (ASC) state characterized by decreasing degrees of liver disease, respectively. The hepatitis B virus is not directly cytopathic for the infected hepatocyte, and $\mathrm{HBV}$-induced liver cell injury and subsequent viral clearance is believed to be mediated by "cellular" immune mechanisms (2). Despite this fact, historically the serology of $\mathrm{CH}-\mathrm{B}$ patients has been reported to be remarkably homogeneous regardless of clinical classification (i.e., $\mathrm{CAH}, \mathrm{CPH}, \mathrm{ASC}$ ) or degree of liver damage. For example, the sera of $\mathrm{CH}-\mathrm{B}$ patients contain $\mathrm{HBV}$ virions, subviral particles composed of excess envelope proteins ( $\mathrm{HBsAg}$ and pre-SAg), a secreted form of the nucleoprotein, the hepatitis $\mathrm{B}$ e antigen ( $\mathrm{HBeAg})$, and antibody to the nucleocapsid (anti-HBc), but remain seronegative for anti-envelope (anti-HBs and anti-pre-S) and anti-HBe antibodies for many years until HBV DNA clearance and loss of serum $\mathrm{HBeAg}$. Serum $\mathrm{HBsAg}$ remains positive in many resolved as well as in unresolved $\mathrm{CH}-\mathrm{B}$ infections, and correspondingly anti-HBs often remains undetectable even after $\mathrm{HBV}$ clearance $(3,4)$.

If cellular immune responses are responsible for liver cell injury and $\mathrm{HBV}$ clearance, there should be serological evidence of these underlying cellular processes. However, the presence of $\mathrm{HBsAg}$ and $\mathrm{HBeAg}$ in the serum may affect the ability to detect circulating antibodies and may obscure the onset of seroconversion. The available commercial assays usually detect anti-HBs and anti-HBe antibodies only after the respective antigens have been cleared from the serum. To address the possibility that antibodies to the structural HBV antigens are produced but not detected in $\mathrm{CH}-\mathrm{B}$ infection, we have developed sensitive immunoassays for the detection of anti-HBe and antienvelope (anti-HBenv) antibodies, regardless of the presence of the antigens in serum (5). We and others $(5,6)$ have utilized a direct binding enzyme immunoassay (EIA) to detect IgG anti-HBe in the sera of $\mathrm{HBeAg}$-positive $\mathrm{CH}-\mathrm{B}$ patients. This EIA method is more sensitive than the commercial anti-HBe assays, which are based on antigen neutralization (5). To detect anti-envelope antibodies in the presence of a vast excess of the particulate HBsAg, a method of detecting IgG anti-HBenv that is immune-complexed to $\mathrm{HBsAg}$ was utilized (5). This report describes the serological analysis of a series of samples from $200 \mathrm{HBsAg}$ and $\mathrm{HBeAg}$-positive $\mathrm{CH}$-B adult patients using these new generation immunoassays. This analysis revealed: $(a)$ the majority of $\mathrm{CH}-\mathrm{B}$ patients do indeed demonstrate ongoing humoral immune responses specific for a number of HBV antigens; $(b)$ three representative serologic profiles of $\mathrm{CH}-\mathrm{B}$ infection were identified; $(c)$ these "silent" immune responses may occur for a number of years prior to liver disease or viral clearance; $(d)$ the quantitative and qualitative characteristics of the immune responses can be correlated with clinical status; and $(e)$ this array of humoral immune responses appears to be mediated exclusively by $\mathrm{HBeAg}$-specific $\mathrm{T}$ helper ( Th ) cells. These results redefine the serological profiles in $\mathrm{CH}$ $B$ infection and may provide the framework for a better under- 
standing of the underlying cellular immune mechanisms responsible for $\mathrm{HBV}$ clearance in chronically infected patients.

\section{Methods}

Recombinant antigens. Recombinant $\mathrm{HBsAg}$ ( $\mathrm{rHBsAg}$ ) minus the pre-S sequences of the subtype $a d w$ was derived from a yeast expression vector (7) and was provided by G. Bitter (Amgen, Thousand Oaks, $\mathrm{CA}$ ). Recombinant $\mathrm{HBcAg}$ of the ayw subtype derived from an Escherichia coli expression vector (8) was provided by F. Schödel (Max Planck Institute, Munich). Recombinant $\mathrm{HBeAg}$ (an $\mathrm{HBcAg}$ deletion mutant lacking the carboxy-terminal 39 amino acids) of the ayw subtype derived from an $E$. coli expression vector (9) was provided by $S$. Stahl (Biogen, Geneva). The rHBeAg was maintained at pH 9.6 and expressed only $\mathrm{HBeAg}$ antigenicity as assessed by reactivity with anti$\mathrm{HBe}$-specific $\mathrm{mAbs}$, and the $\mathrm{rHBcAg}$ expressed only $\mathrm{HBcAg}$ antigenicity as determined by reactivity with anti-HBc-specific mAbs (10). An $E$. coli-derived recombinant polypeptide comprised of the pre-S(1) and pre-S(2) domains $[\operatorname{pre}(\mathrm{S} 1+\mathrm{S} 2)]$ and devoid of $\mathrm{S}$ region sequences of the HBV envelope (11) was provided by D. Peterson (Virginia Commonwealth University, Richmond, VA).

Antibody reagents. Monoclonal anti-HBs ( $1 \mathrm{~B} 1 \mathrm{E} 7 \mathrm{~F} 7)$ and peroxidase conjugated $\mathrm{mAb}$ anti-human IgG was obtained from Ortho Diagnostics Systems, Inc., (Raritan, NJ). HBcAg-specific mAb 3105 and 3120 (12); and HBeAg-specific mAb 904, 905 (13) and 2221 (14); and pre-S(2)-specific mAb 4408 (15) were provided by M. Mayumi (Jichi Medical School, Tochigi-Ken, Japan). Peroxidase conjugated $\mathrm{mAb}$ anti-human $\mathrm{IgG}_{1}, \mathrm{IgG}_{2}, \mathrm{IgG}_{3}$, and $\mathrm{IgG}_{4}$ were purchased from $\mathrm{Zymed}$ Labs, Inc. (San Francisco, CA ). Polyclonal rabbit anti-peptide antibodies were prepared by immunizing rabbits with synthetic peptides representing $\mathrm{HBsAg} / \mathrm{ad} w$ residues $125-137$ (16) and $\mathrm{HBeAg}$ residues 73-87 (5) and IgG fractions were obtained by ion exchange chromatography (Econo-Pac 10 DG; Bio-Rad/Analytical Instr. Group, Cambridge, MA).

Direct solid-phase enzyme immunoassays. Solid-phase enzyme immunoassays (EIA) were used to measure serum anti-HBc, anti-HBe and anti-pre-S antibody levels. Recombinant $\mathrm{HBcAg}, \mathrm{HBeAg}$, or pre$(\mathrm{S} 1+\mathrm{S} 2)$ diluted in $0.01 \mathrm{M}$ bicarbonate buffer, $\mathrm{pH}$ 9.6, were coated onto microtiter plates $\left(50 \mathrm{ng} /\right.$ well) overnight at $4^{\circ} \mathrm{C}$. Between each step, the plates were washed five times in PBS with $0.1 \%$ BSA and $0.005 \%$ Tween 20 . The plates were pre-incubated for $1 \mathrm{~h}$ at $37^{\circ} \mathrm{C}$ with $50 \mu \mathrm{l}$ of PBS containing $1 \%$ BSA, $0.005 \%$ Tween 20 and $5 \%$ heat-inactivated goat serum (blocking buffer) to reduce nonspecific binding. Human sera were diluted in blocking buffer and added to the plates and incubated for $2 \mathrm{~h}$ at $37^{\circ} \mathrm{C}$. The plates were washed and incubated with $50 \mu$ l of peroxidase conjugated anti-human $\operatorname{IgG}(1: 2,500)$ or anti-human IgG subclass-specific mAbs (1:500) for $2 \mathrm{~h}$ at $37^{\circ} \mathrm{C}$. The plates were developed by a final incubation for $10 \mathrm{~min}$ with $50 \mu \mathrm{l}$ of orthophenylene diamine (OPD). The absorbance was read on an automatic microtiter plate reader ( model MR600; Dynatech Labs Inc., Chantilly, VA). In preliminary experiments using 62 patient sera, there was a significant correlation $(P<0.001)$ between end point titer determined by serial dilution of serum samples and the OD value of a single appropriate dilution. Therefore, the results are expressed in optical density $\left(\mathrm{OD}_{492 \mathrm{~nm}}\right)$ units for one serum dilution from each patient. The dilution chosen was based on titration analysis of representative serum samples. In each assay at least 15 sera, which were negative for all HBV markers, were used as negative controls. The data are expressed as a $P / N$ ratio which represents the absorbance $\left(\mathrm{OD}_{492}\right)$ value of the sample $(P)$ as compared to the mean absorbance value of at least 15 negative control sera $(N)$.

HBsAg/anti-HBenv immune complex assay. To detect $\mathrm{HBsAg} /$ anti-HBenv immune complexes (IC's) in serum a solid-phase EIA was developed (5). Briefly, plates were coated with an IgG fraction of antiHBs peptide 125-137 (0.5 $\mu \mathrm{g} /$ well $)$ as the solid-phase capture reagent. This anti-peptide efficiently binds native $\mathrm{HBsAg}$ but does not compete with anti-HBs antibodies raised against native $\mathrm{HBsAg}$, and therefore can bind HBsAg that is simultaneously complexed to serum anti-HBs antibodies. The bound serum anti-HBenv is then detected with a peroxidase-labeled anti-human IgG second antibody. During the course of this study it was observed that mAb anti-HBs (1B1E7F7) could substitute for the anti-peptide IgG fraction as the solid-phase capture reagent due to the fact that the $\mathrm{HBsAg} /$ anti-HBenv immune complexes were formed in $\mathrm{HBsAg}$ excess in $\mathrm{CH}-\mathrm{B}$ patient sera, and competition between solid-phase anti-HBs and serum anti-HBenv was not limiting. The data are expressed as a $P / N$ ratio, which represents the absorbance $\left(\mathrm{OD}_{492}\right)$ value of the sample $(P)$ as compared to the mean absorbance value of at least 15 control sera $(N)$. A similar EIA was used to detect serum $\mathrm{HBeAg} /$ anti-HBe immune complexes using an IgG fraction of anti-HBe peptide 73-87 as the solid-phase capture reagent (5), however, only the anti-HBe results derived from the direct EIA are reported.

Western immunoblot analysis. Recombinant $\mathrm{HBeAg}$ was separated on a $15 \%$ sodium dodecyl sulfate-polyacrylamide gel according to the method of Laemmli (17), and transferred to a nitrocellulose membrane. The membrane was immersed in $1 \%$ skim milk in TBS $(20 \mathrm{mM}$ Tris- $\mathrm{HCl}, \mathrm{pH} 7.6,0.5 \mathrm{M} \mathrm{NaCl}$ ), and each strip was successively incubated with a 1:20 dilution of patient serum for $2 \mathrm{~h}$ at room temperature, biotinylated anti-human IgG, peroxidase-conjugated avidin, and finally developed with 4-chloro-1-naphthol.

Quantitative measurement of $\mathrm{HBsAg}$, pre-S Ag, and $\mathrm{HBeAg}$ in serum. Solid-phase EIAs were developed to measure $\mathrm{HBsAg}$ and pre-S $\mathrm{Ag}$ levels in serum. For the detection of $\mathrm{HBsAg}, \mathrm{mAb}$ anti-HBs (1B1E7F7) was used, and for the detection of pre-S-containing HBsAg, mAb anti-pre-S $(2)(4408)$ was used as the solid phase capture reagent ( $25 \mathrm{ng} /$ well). Sera to be tested were diluted 1:10 in blocking buffer and added to the mAb-coated plates. Rabbit anti-HBs peptide 125-137 served as the second antibody, and peroxidase-labeled goat anti-rabbit $\mathrm{IgG}$ was used as the probe. A standard curve was obtained using serially diluted $\mathrm{rHBsAg}$ or $\mathrm{rHBsAg}$ containing pre-S(1) and pre-S(2) sequences as standards. Quantitation of serum $\mathrm{HBeAg}$ levels was performed using the Abbott $\mathrm{HBeAg}$ EIA kit (Abbott Labs, Chicago, IL) and $\mathrm{rHBeAg}$ was used as the standard.

Patients. 200 adult chronic HBV carrier patients who were consistently positive for both $\mathrm{HBsAg}$ and $\mathrm{HBeAg}$ in their serum for more than $1 \mathrm{yr}$ were subjects in this study. They were followed at the First Department of Internal Medicine, Tokyo University (Tokyo, Japan). They consisted of $45 \mathrm{ASC}, 34 \mathrm{CPH}, 105 \mathrm{CAH}$, and $16 \mathrm{LC}$ patients. The diagnosis of liver disease was made according to Leevy, Popper, and Sherlock ( 18). All sera were tested for $\mathrm{HBsAg}$ /anti-HBs, $\mathrm{HBeAg} /$ anti$\mathrm{HBe}$, anti-HBc, IgM-anti-HBc, anti-HDV, and anti-HCV using commercial enzyme immunoassays (EIAs; Abbott Laboratories). All patients were negative for anti-HDV and anti-HCV antibodies. In the Abbott assay anti-HBe was expressed as a percentage of inhibition, and an inhibition of more than $50 \%$ is considered positive for anti-HBe. HBV-DNA was determined using a dot blot procedure (19). Comparisons between mean values were determined by Student's $t$ test. Differences in frequency rates were determined by Chi-square analysis. A $P$ value $<0.05$ was considered significant.

\section{Results}

Prevalence of anti-HBe antibody production in $\mathrm{CH}-\mathrm{B}$ infection. The sera of $200 \mathrm{HBsAg}$ and $\mathrm{HBeAg}$-positive $\mathrm{CH}-\mathrm{B}$ patients were screened for the presence of $\mathrm{HBeAg}$-specific antibodies using a direct solid-phase EIA. All 200 sera were negative for anti-HBe antibody by the commercial Abbott neutralization assay. As shown in Fig. 1, virtually all $\mathrm{HBeAg}$-positive patients with chronic liver disease (105/105 $\mathrm{CAH}, 33 / 34 \mathrm{CPH}$, and $16 / 16 \mathrm{LC}$ ) possessed IgG anti-HBe antibodies in their serum. In contrast, $\mathrm{HBeAg}$-positive asymptomatic carrier (ASC) patients could be divided into two subgroups, one (55.6\%) which produced IgG anti-HBe antibody and the other $(44.4 \%)$ in 


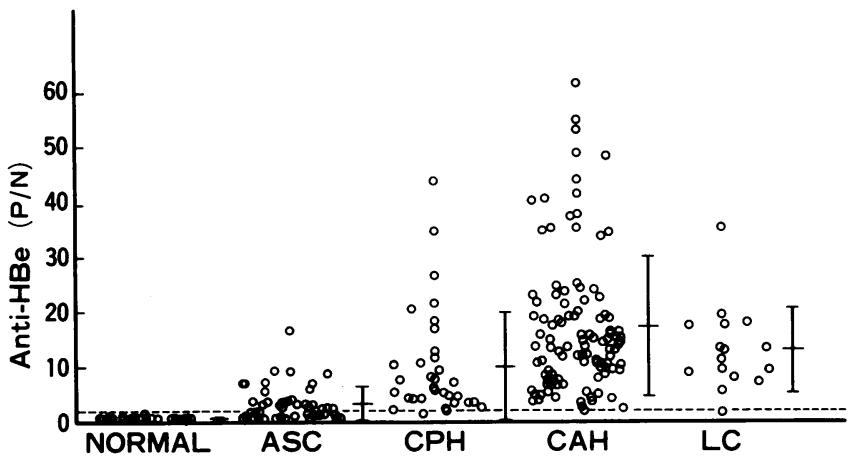

Figure 1. Prevalence of anti-HBe antibody production in $\mathrm{CH}-\mathrm{B}$ carriers determined by direct EIA. Serum IgG anti-HBe antibody levels in $\mathrm{HBeAg}$-positive chronic $\mathrm{HBV}$ carriers with varying degrees of liver injury were measured by direct solid-phase EIA. Recombinant $\mathrm{HBeAg}$ served as the solid-phase ligand coated onto microtiter plates ( $50 \mathrm{ng} /$ well), and was incubated with 1:50 dilutions of patient sera. A peroxidase-labeled monoclonal anti-human IgG was used as the second antibody. The data are expressed as $P / N$ ratio, which represents the absorbance $\left(\mathrm{OD}_{492}\right)$ value of the sample $(P)$ as compared to the mean absorbance value of 23 normal healthy control sera $(N)$, which was $0.03 \pm 0.011$. Significant differences were observed between normals versus ASC $(P<0.001)$, ASC versus CPH $(P<0.001)$, ASC versus CAH $(P<0.001)$, ASC versus LC $(P<0.001)$, and between $\mathrm{CPH}$ versus $\mathrm{CAH}(P<0.01)$.

which anti-HBe antibody was not detected. The mean level of anti-HBe was significantly higher in patients with $\mathrm{CAH}$ as compared to those with $\mathrm{CPH}, \mathrm{LC}$, or $\mathrm{ASC}(P<0.001)$. These results indicate that the direct EIA is significantly more sensitive in the detection of anti-HBe antibodies in serum as compared to the commercial assay as previously noted $(5,6)$, and that $\mathrm{IgG}$ anti-HBe antibody production is occurring in $\mathrm{HBeAg}$ positive $\mathrm{CH}-\mathrm{B}$ patients to a much greater extent than previously realized. Because antibody production to $\mathrm{HBeAg}$ is a $\mathrm{T}$ helper ( Th ) cell-dependent process (10), these results also indicate a high incidence of Th cell sensitization to $\mathrm{HBeAg}$ in $\mathrm{CH}-\mathrm{B}$ patients. Although the level of anti-HBe antibody production correlates with the degree of liver disease, anti-HBe production per se does not predict liver disease because $55.4 \%$ of ASC patients also produce anti-HBe, albeit at lower levels.

Kinetics of anti-HBe production during the spontaneous clearance of $H B V$ infection. Temporal serum samples from 24 HBeAg-positive CH-B patients who spontaneously demonstrated a sustained clearance of HBV-DNA, loss of serum $\mathrm{HBeAg}$, and clinical remission of liver disease were analyzed for IgG anti-HBe production by the direct EIA method and by the commercial (Abbott) anti-HBe assay. The first sample in the series consisted of the first available serum sample from each patient, which ranged from 7 to 78 mo (mean $=29.1 \pm 17.1 \mathrm{mo}$ ) before the spontaneous loss of serum $\mathrm{HBeAg}$. Subsequent samples analyzed for anti-HBe were taken 3-6 mo and 1-2 mo before $\mathrm{HBeAg}$ loss and 1-2 mo and 3-6 mo after $\mathrm{HBeAg}$ was no longer detectable in the serum. All 24 $\mathrm{CH}-\mathrm{B}$ patients demonstrated anti-HBe antibody as determined by the direct EIA in their first available serum sample, and the mean anti-HBe levels gradually increased from the first sample until 1-2 mo prior to $\mathrm{HBeAg}$ loss $(P<0.01)$ (Fig. $2 A)$. Note that the direct EIA was capable of detecting IgG anti-HBe in the presence of $\mathrm{HBeAg}$. The specificity of the anti-HBe for
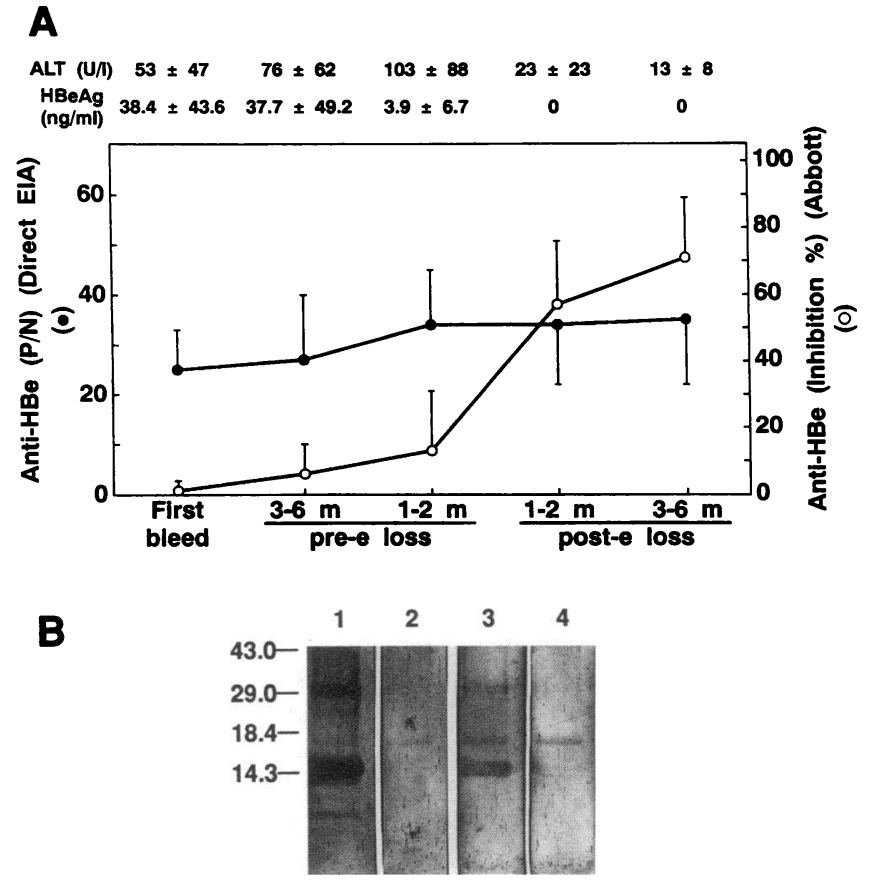

Figure 2. $(A)$ Kinetics of anti-HBe antibody production during spontaneous seroconversion in $\mathrm{CH}-\mathrm{B}$ patients. Anti-HBe antibody levels in sequential serum samples of $24 \mathrm{HBeAg}$-positive patients with $\mathrm{CH}-\mathrm{B}$ who demonstrated spontaneous sustained clearance of HBV-DNA and loss of $\mathrm{HBeAg}$ were measured by direct EIA and by a commercial (Abbott) assay. In each patient, sera were collected at the first available time, 3-6 mo before loss of $\mathrm{HBeAg}, 1-2$ mo before loss of $\mathrm{HBeAg}, 1-2 \mathrm{mo}$ after loss of $\mathrm{HBeAg}$, and 3-6 mo after loss of $\mathrm{HBeAg}$. The commercial anti-HBe assay was performed according to the manufacturer's instructions, using undiluted sera, and the direct EIA method described in Fig. 1 utilized 1:50 dilutions of sera. The data are expressed as percent inhibition in the commercial assay (open circle) and as $P / N$ ratio in the direct EIA (closed circle). In the commercial assay, an inhibition value of $50 \%$ or greater is considered as positive for anti-HBe. Mean $\mathrm{HBeAg}(\mathrm{ng} / \mathrm{ml})$ serum concentrations and ALT (U/liter) values for each time point are also shown. $(B)$ Confirmation of anti-HBe antibody production by Western immunoblot analysis. In lanes 1 and 2, rHBeAg-specific polypeptides of 15.5 and $31 \mathrm{kD}$ were recognized by an $\mathrm{HBeAg}$-negative, anti-HBe-positive control serum, and in lanes 3 and 4 by an $\mathrm{HBeAg}$-positive, anti-HBe-positive $\mathrm{CH}-\mathrm{B}$ patient serum representative of the sera analyzed in Fig. $2 A$. In lanes 2 and 4, sera were preabsorbed with $5.0 \mu \mathrm{g}$ of $\mathrm{rHBeAg}$ overnight at $4^{\circ} \mathrm{C}$ before immunoblotting. Anti-HBe-negative normal serum did not immunoblot the $\mathrm{HBeAg}$-specific polypeptides (not shown).

native serum $\mathrm{HBeAg}$ as well as the recombinant solid-phase $\mathrm{HBeAg}$ is confirmed by the presence of HBeAg-specific IC's in the sera of these patients ( not shown). In contrast to the results using the direct EIA, anti-HBe was not detected by the commercial assay until 1-2 mo after the disappearance of $\mathrm{HBeAg}$ from serum. These results indicate that $\mathrm{HBeAg}$-specific Th cell sensitization and subsequent anti-HBe antibody production can occur many years before the loss of $\mathrm{HBeAg}$ from the serum in $\mathrm{CH}-\mathrm{B}$ patients.

Because all $\mathrm{CH}-\mathrm{B}$ patients produce anti-HBc antibodies (see Fig. $3 \mathrm{~A}$ ), it is necessary to distinguish the anti-HBe antibodies detected in the direct EIA from anti-HBc antibody. Firstly, in $44.4 \%$ of anti-HBc-positive ASC patients no anti- 


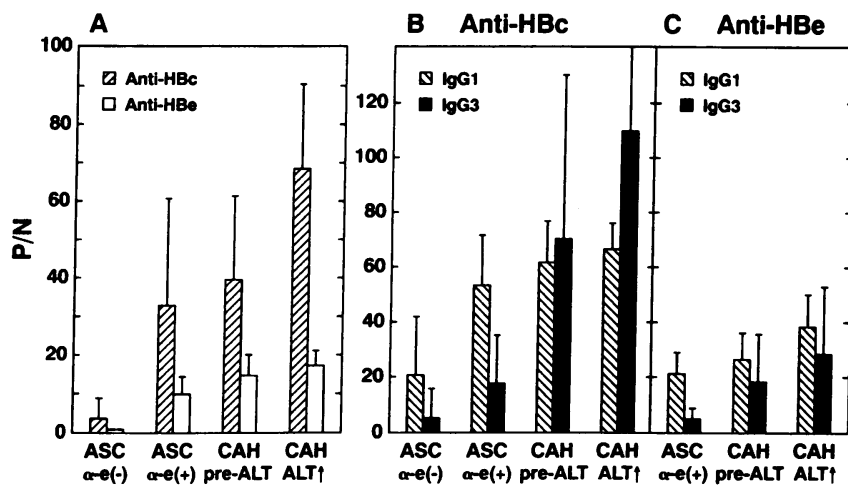

Figure 3. $(A)$ Comparative anti-HBc and anti-HBe production in $\mathrm{CH}-\mathrm{B}$ patients. The sera of 20 anti-HBe-negative ASC patients, 12 anti-HBe-positive ASC patients, and paired serum samples from $\mathrm{CAH}$ patients in the resting phase (pre-ALT) and during a period of liver injury (ALT $\uparrow$ ) were analyzed for anti-HBc (sera diluted 1:102,400) and anti-HBe (sera diluted 1:800) antibodies by direct EIA. All patients were $\mathrm{HBeAg}$-positive. The data are expressed as $P / N$ ratio. Significant differences were observed in the levels of anti-HBc between anti-HBe $(-)$ ASC versus anti-HBe $(+) \operatorname{ASC}(P<0.001)$, anti-HBe $(+)$ ASC versus CAH (ALT $\uparrow)(P<0.01)$, and CAH (preALT) versus CAH $($ ALT $\uparrow)(P<0.05)$. In terms of levels of anti$\mathrm{HBe}$, significant differences were noted between anti-HBe (-) ASC versus anti-HBe $(+) \mathrm{ASC}(P<0.001)$, anti-HBe $(+)$ ASC versus $\mathrm{CAH}(\mathrm{ALT} \uparrow)(P<0.001)$, and anti-HBe $(+)$ ASC versus CAH (pre-ALT) $(P<0.05)$. IgG subclass distribution of anti-HBc $(B)$ and anti-HBe $(C)$ antibodies in $\mathrm{CH}-\mathrm{B}$ patients. The sera analyzed for total IgG anti-HBc and anti-HBe in Fig. $3 \mathrm{~A}$ were examined for anti-HBc and anti-HBe antibodies of the $\mathrm{IgG}_{1}$ and $\mathrm{IgG}_{3}$ subclasses. Sera were diluted 1:3,200 for IgG subclass analysis of anti-HBc antibodies, and 1:800 for IgG subclass analysis of anti-HBe antibodies. The data are expressed as $P / N$ ratio. Significant differences in $I_{g G}$ anti-HBc levels were observed between anti-HBe (-) ASC versus anti-HBe (+) ASC $(P<0.001)$, and between anti-HBe $(+)$ ASC versus CAH (ALT $\uparrow)$. In terms of $\mathrm{IgG}_{3}$ anti- $\mathrm{HBc}$ levels, significant differences were observed between anti-HBe (-) ASC versus CAH (pre-ALT) or CAH $($ ALT $\uparrow)(P<0.001)$, and between anti-HBe $(+)$ ASC versus CAH (pre-ALT) $(P<0.05)$ or CAH (ALT $\uparrow)(P<0.001)$. With respect to $\mathrm{IgG}_{1}$ anti-HBe levels, a significant difference was noted between anti-HBe $(+)$ ASC versus CAH (ALT $\uparrow)(P<0.001)$. In terms of $\mathrm{IgG}_{3}$ anti-HBe levels, significant differences were observed between anti-HBe $(+)$ ASC versus CAH (ALT $\uparrow)(P<0.01)$, and between anti-HBe $(+)$ ASC versus CAH (pre-ALT) $(P<0.05)$.

$\mathrm{HBe}$ antibodies are detected. The anti-HBe reactivity that is detected by the direct EIA in CAH patient sera can be quantitatively inhibited by the addition of $\mathrm{rHBeAg}$ but not by the addition of $\mathrm{rHBcAg}$ (not shown). Furthermore, $\mathrm{HBcAg}$-specific mAb's 3105 plus 3120 inhibit $100 \%$ of anti-HBc reactivity in an anti-HBc-specific EIA but do not inhibit the anti-HBe reactivity in the anti-HBe-specific EIA (not shown). Finally, a representative $\mathrm{CH}-\mathrm{B}$ patient sera positive for both $\mathrm{HBeAg}$ and anti-HBe antibody as depicted in Fig. $2 A$ contained sufficient anti-HBe to react with the $\mathrm{HBeAg}$-specific polypeptides of 15.5 and 31 (dimer) $\mathrm{kDa}$ in a Western immunoblotting assay (Fig. $2 B$, lane 3 ).

Comparative anti-HBc and anti-HBe antibody production and IgG subclass distribution in $\mathrm{CH}$-B patients. Anti-HBc antibody can be produced via $T$ cell-independent and T cell-dependent pathways (20). The cross-reactivity of Th cell recognition of $\mathrm{HBcAg}$ and $\mathrm{HBeAg}(10)$ predicts a correlation between the $\mathrm{T}$ cell-dependent pathway of anti-HBc antibody production and anti-HBe antibody production. Therefore, it was of interest to compare anti-HBc and anti-HBe antibody levels in $\mathrm{CH}-\mathrm{B}$ patient sera. As previously noted, ASC patients can be divided into anti-HBe producers and anti-HBe non-producers. As shown in Fig. $3 A$, ASC patients capable of producing anti-HBe possessed significantly higher levels of IgG anti-HBc $(P / N$ $33.0 \pm 28.1)$ as compared to anti-HBe-negative ASC patients $(P / N 3.7 \pm 5.5)$. The positive correlation between anti-HBc and anti-HBe antibody production has not been previously appreciated because of the inability to detect anti-HBe in $\mathrm{HBeAg}$-positive $\mathrm{CH}-\mathrm{B}$ patients. The relatively low anti-HBc titers observed in anti-HBe-negative ASC patients is consistent with $\mathrm{T}$ cell-independent anti-HBc antibody production, and reflects a deficit in $\mathrm{HBe} / \mathrm{HBcAg}$-specific $\mathrm{Th}$ cell function. Anti-HBc and anti-HBe levels were also examined in $\mathrm{CAH}$ patients, and compared to ASC patients. To control for the effects of active liver disease in $\mathrm{CAH}$, paired serum samples from each $\mathrm{CAH}$ patient were selected to represent a resting phase sample (i.e., serum alanine aminotransferase (ALT) $<35 \mathrm{U} /$ liter for at least a 6-mo period) and a sample taken during a period of active liver disease reflected by an elevated ALT value ( $>150 \mathrm{U} /$ liter). During periods of active liver disease anti-HBc antibody levels were significantly elevated $(P$ $<0.01$ ) as compared to periods without disease in the same $\mathrm{CAH}$ patients and as compared to ASC patients (Fig. $3 \mathrm{~A}$ ). However, anti-HBc levels were not significantly different between anti-HBe-positive ASC patients and $\mathrm{CAH}$ patients in a resting phase. Anti-HBe antibody levels were higher in $\mathrm{CAH}$ patients with or without liver disease as compared to anti-HBepositive ASC patients. However, a much greater difference between anti-HBe-positive ASC and $\mathrm{CAH}$ patients emerged when the IgG subclass profile of anti-HBc and anti-HBe antibody production was examined (Fig. $3 B$ and $C$ ). Although total IgG and $\mathrm{IgG}_{1}$ subclass anti-HBc antibody levels were similar between anti-HBe-positive ASC patients and $\mathrm{CAH}$ patients in the resting phase, the ASC patients produced minimal anti$\mathrm{HBc}$ of the $\mathrm{IgG}_{3}$ subclass, whereas in the $\mathrm{CAH}$ patients the $\mathrm{IgG}_{3}$ subclass of anti-HBc was dominant or co-dominant with $\mathrm{IgG}_{1}$. The low level production of $\mathrm{IgG}_{3}$ subclass anti-HBc antibodies exhibited by the anti-HBe-positive ASC patients was extended to the anti-HBe antibodies produced by these patients as well (Fig. $3 C$ ). The anti-HBe-negative ASC patients produced significantly less $\mathrm{IgG}_{1}$ anti-HBc antibody as compared to all other patient groups $(P<0.001)$, and practically no $\mathrm{IgG}_{3}$ anti-HBc antibodies (Fig. $3 \mathrm{~B}$ ). Most patients in all categories did not produce significant $\mathrm{IgG}_{2}$ or $\mathrm{IgG}_{4}$ subclass antibodies, and $\mathrm{IgM}$ anti-HBc and anti-HBe levels in $\mathrm{CH}-\mathrm{B}$ patients were not informative (not shown).

The defect in production of $\mathrm{IgG}_{3}$ subclass anti-HBc antibodies in both subgroups of ASC patients, and $\mathrm{IgG}_{3}$ anti-HBe antibodies in anti-HBe-positive ASC patients is notable, and provides a further serological distinction between asymptomatic and symptomatic $\mathrm{CH}-\mathrm{B}$ carriers. The low level production of $\mathrm{IgG}_{3}$ subclass antibodies by ASC patients is unlikely to represent an antigen-specific $B$ cell defect because antibody production to both $\mathrm{HBcAg}$ and $\mathrm{HBeAg}$ are affected. Because $\mathrm{HBcAg}$ and $\mathrm{HBeAg}$ are cross-reactive at the level of Th cell recognition, low level $\mathrm{IgG}_{3}$ subclass anti-HBc and anti-HBe production most likely reflects a defect in $\mathrm{HBe} / \mathrm{HBcAg}$-specific $\mathrm{Th}$ cell function in anti-HBe-positive ASC patients as was noted in the anti-HBe-negative ASC subgroup, which is unable to produce anti-HBe at all and produces low level anti-HBc antibody. 


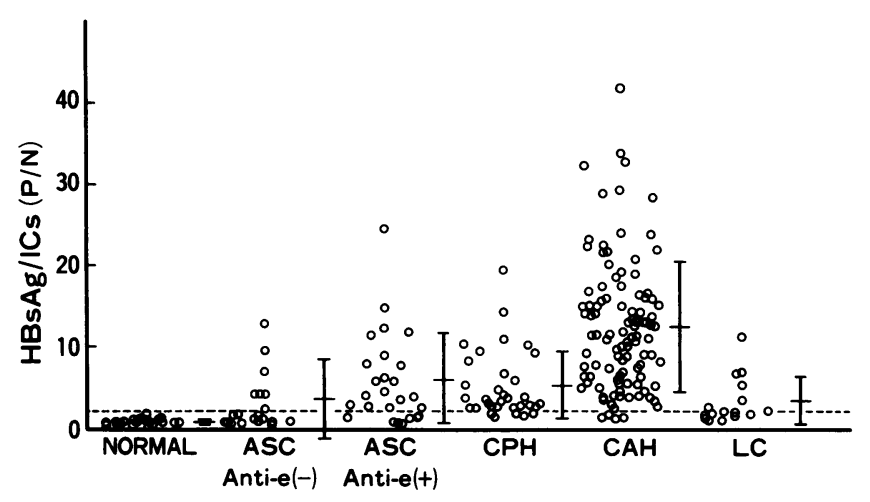

Figure 4. Prevalence of anti-envelope antibody production in $\mathrm{CH}-\mathrm{B}$ patients. Anti-envelope antibody production was determined by measuring $\mathrm{HBsAg} /$ anti-HBenv containing immune complexes in CH-B patient sera ( 1:50 dilution) using the solid-phase EIA described in the Methods section. Two hundred HBeAg-positive chronic HBV carriers with varying degrees of liver injury were analyzed. The data are expressed as $P / N$ ratio, which represents the absorbance $\left(\mathrm{OD}_{492}\right)$ value of the sample $(P)$ as compared to the mean absorbance value of 23 negative control sera $(N)$, which was $0.046 \pm 0.024$. Significant differences were observed between normals versus anti-HBe (+) ASC, $\mathrm{CPH}, \mathrm{CAH}$, and $\mathrm{LC}(P<0.001)$; between anti-HBe $(-)$ ASC versus $\mathrm{CAH}(P<0.001)$, anti-HBe $(+)$ ASC versus CAH $(P<0.001)$, normals versus anti-HBe $(-)$ ASC $(P<0.05)$, and between anti-HBe $(-)$ ASC versus anti-HBe $(+)$ ASC $(P<0.05)$

Prevalence of anti-envelope antibody production in $\mathrm{CH}-\mathrm{B}$ infection. Historically, the detection of anti-HBs and anti-pre-S antibodies in the serum of $\mathrm{CH}-\mathrm{B}$ patients has been complicated by the secretion of excess quantities of the multivalent, particulate envelope antigens. Previous reports of $\mathrm{HBsAg-containing}$ immune complexes in $\mathrm{CH}-\mathrm{B}$ patients have suggested that these patients can produce anti-envelope antibodies (21-25). In the series of $\mathrm{CH}-\mathrm{B}$ patients studied herein, no anti-HBs antibodies were detected before clearance of HBV-DNA using a commer- cial (Abbott) anti-HBs antibody assay, and only a low incidence of anti-HBs and anti-pre-S antibodies was detected using direct solid-phase EIAs (not shown). To circumvent the problem of detecting antibody in the presence of antigen excess, we screened $\mathrm{CH}$-B patient sera for anti-envelope antibodies, which may be complexed to circulating $\mathrm{HBsAg}$, using an HBsAg-specific immune complex (IC) assay as described (5). This assay does not distinguish between immune complexes formed by the interaction of $\mathrm{HBsAg}$ particles with anti-HBs and/or anti-pre-S-specific antibodies. In contrast to the results obtained with less sensitive methods, HBeAg-positive, HBsAgpositive $\mathrm{CH}-\mathrm{B}$ patients with chronic liver disease demonstrated a high incidence of anti-envelope antibody production demonstrated by the presence of HBsAg-specific IC's in serum (101/ $105 \mathrm{CAH}, 29 / 34 \mathrm{CPH}$, and 8/16 LC) (Fig. 4). Similarly, anti$\mathrm{HBe}$-positive ASC patients also demonstrated a high incidence of anti-envelope antibody production (18/25), and anti-HBenegative ASC patients demonstrated a significantly lower incidence of anti-envelope antibody production $(6 / 20, P<0.02)$.

Kinetics of anti-envelope antibody production in $\mathrm{CAH}$ patients. In order to examine the kinetics of anti-envelope antibody production, temporal serum samples from $32 \mathrm{CAH}$ patients were examined spanning a time frame from 6 mo prior to an acute exacerbation (AE) of liver injury (ALT > 150 U/ liter) to $6 \mathrm{mo}$ after the AE for each patient. Total anti-envelope antibody was measured in the $\mathrm{HBsAg} / \mathrm{IC}$ assay, and anti-pre$S$-specific antibody was measured in a direct EIA using recombinant pre- $(\mathrm{S} 1+\mathrm{S} 2)$ as the solid-phase ligand. As shown in Fig. $5 A$, the mean $\mathrm{HBsAg} / \mathrm{IC}$ levels increased to a $P / N$ value of 8.6 at the peak of ALT elevation, and then declined rather rapidly thereafter. Similarly, anti-pre-S antibody levels increased and decreased in parallel with $\mathrm{HBsAg} / \mathrm{IC}$ 's and ALT values. The marked decline in $\mathrm{HBsAg} / \mathrm{IC}$ 's in the months after the ALT elevation could reflect either the clearance of the antigen or diminished anti-envelope antibody production. To address this issue, the serum concentrations of $\mathrm{HBsAg}$ and pre-Scontaining $\mathrm{HBsAg}$ were determined in paired serum samples
A

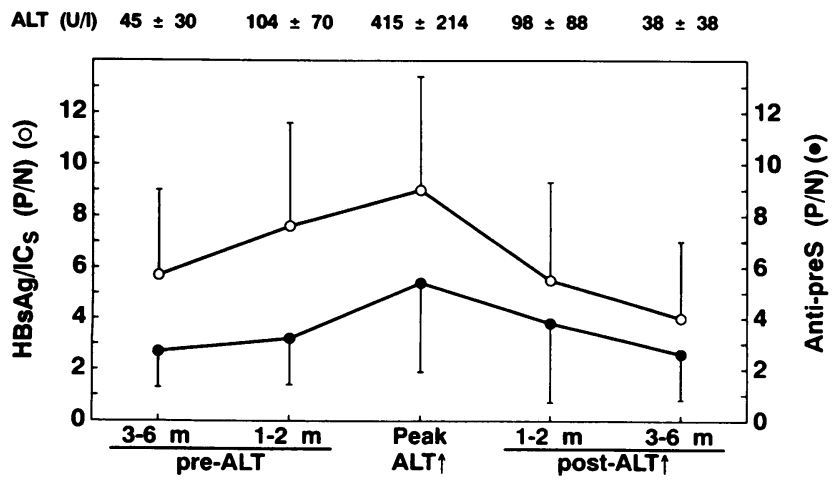

B

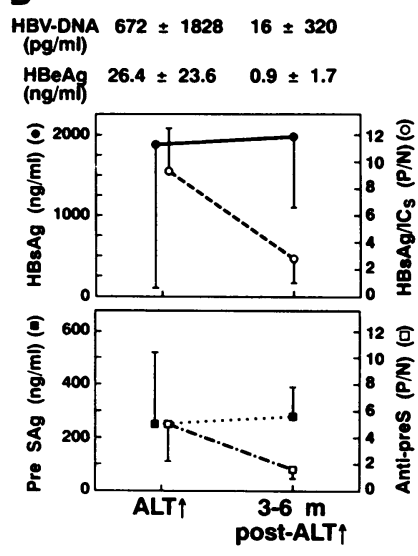

Figure 5. (A) Kinetics of anti-envelope antibody production in $\mathrm{CAH}$ patients. The sequential sera (1:50) of $32 \mathrm{CAH}$ patients who developed acute exacerbations of liver injury were analyzed for anti-HBenv antibody production. Total anti-HBenv production was measured in the $\mathrm{HBsAg} / \mathrm{IC}$ assay (open circle), and anti-preS specific antibody (closed circle) was measured by a direct EIA using recombinant pre $(\mathrm{S} 1+\mathrm{S} 2)$ as the solid-phase ligand. In each patient, sera were collected 3-6 mo before and 1-2 mo before an ALT elevation (pre-ALT); during the peak of ALT elevation; 1-2 mo after and 3-6 mo after an ALT peak

(post-ALT $\uparrow$ ). Mean ALT levels are shown for each time point. The data are expressed as $P / N$ ratio, $N=0.041 \pm 0.012$, IC assay; $N$ $=0.031 \pm 0.012$ anti-pre-S assay. $(B)$ Serum HBsAg and preS antigen concentrations do not change as anti-HBenv antibody production declines. Nine paired sera from CAH patients who showed marked ( $>50 \%$ ) decreases in anti-HBenv antibody production 3-6 mo after a period of peak liver injury (ALT $\uparrow$ ) were analyzed for $\mathrm{HBsAg}(\bullet-\bullet)$, pre-S Ag $(\bullet-\bullet)$, anti-HBs-containing IC's $(0-0)$ and anti-pre-S antibody ( $\square-\square)$ as described in the Methods section. The $\mathrm{HBeAg}(\mathrm{ng} / \mathrm{ml})$ and $\mathrm{HBV}$ DNA $(\mathrm{pg} / \mathrm{ml})$ serum concentrations are also shown. Significant differences were observed in anti-HBenv antibody production (i.e., $\mathrm{HBsAg} / \mathrm{IC}$ 's and anti-pre-S) during periods of elevated ALT as compared with 3-6 mo post-ALT elevations $(P<0.001)$. 
from $\mathrm{CAH}$ patients who demonstrated the greatest decrease in HBsAg/IC levels and who did not clear serum HBsAg 3-6 mo after the ALT peak (Fig. $5 \mathrm{~B}$ ). Although $\mathrm{HBsAg} / \mathrm{IC}$ 's declined precipitously during the 3-6 mo period after the ALT peak, the HBsAg serum levels remained unchanged (Fig. 5 B, top). Similarly, pre-S antigen concentrations did not decline, although anti-pre $S$ antibody levels decreased in the post-ALT samples (Fig. $5 \mathrm{~B}$, bottom). Therefore, the decline in immune complex formation reflects decreased anti-envelope antibody production even though the antigen concentrations were not changing during this time period. It is also notable that $\mathrm{HBeAg}$ and serum HBV DNA concentrations significantly declined during the 3-6-mo period after the ALT peak. The decline in anti-envelope antibody production in the context of continued $\mathrm{HBsAg}$ and pre-S Ag production indicates that HBsAg or pre-SAg-spe-
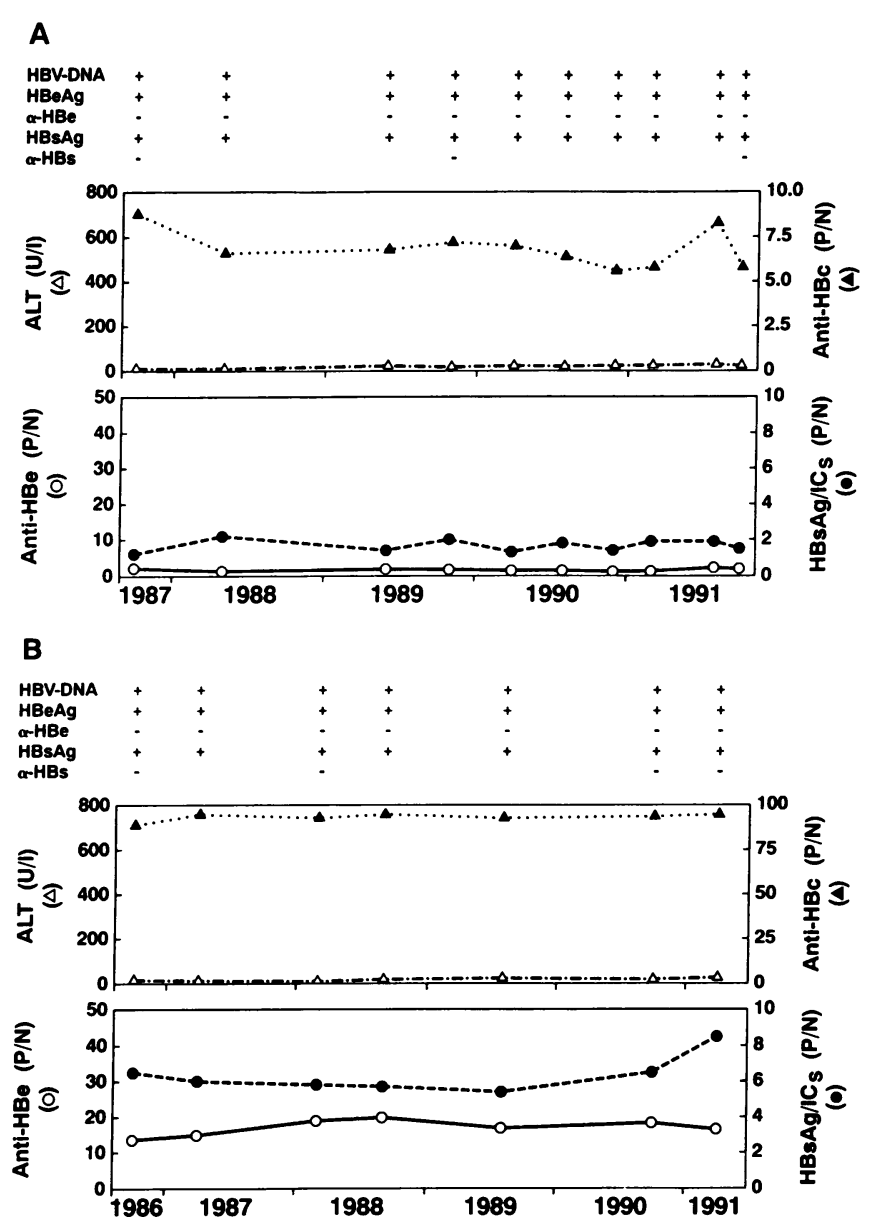

Figure 6. Serologic profiles of two patients representative of antiHBe-negative $(A)$ and anti-HBe-positive $(B)$ asymptomatic $\mathrm{CH}-\mathrm{B}$ carriers. Serum samples were collected during the indicated time frames from K.K., a 25-yr-old anti-HBe-negative ASC patient $(A)$, or T.Y., a 21-yr-old anti-HBe-positive ASC patient $(B)$, and analyzed for $\mathrm{HBV}-\mathrm{DNA}$ (dot hybridization); $\mathrm{HBeAg}, \mathrm{HBsAg}$, anti-HBe, and anti-HBs (commerical assays, Abbott) (top); and ALT levels (U/ liter). The same samples were assayed for anti-HBc $(\Delta-\Delta)$, anti-HBe $(\mathrm{O}-\mathrm{O})$ and $\mathrm{HBsAg} / \mathrm{ICs}(\bullet-\bullet)$ by direct EIA methods as described in Methods. The results of the HBV DNA assay and the commercial assays are expressed as $(+)$ or $(-)$, the EIA data are expressed as $P / N$ ratio. The sera were diluted 1:50 for the anti-HBe and $\mathrm{HBsAg} /$ IC's assays and $1: 100(A)$ or 1:3,200 $(B)$ for the anti-HBc EIAs. Sera were utilized undiluted in the commercial assays. cific Th cells do not regulate the anti-HBenv antibody response. Furthermore, the correlation between anti-envelope antibody production and $\mathrm{HBeAg}$ and $\mathrm{HBV}$ DNA levels suggests that $\mathrm{HBe} / \mathrm{HBcAg}$-specific Th cells may mediate anti-envelope antibody production in CH-B patients via an intermolecular/intrastructural Th cell mechanism as previously described in a murine model (26).

Three representative serological patterns of $\mathrm{CH}-\mathrm{B}$ infection. K.K. is a 25 -yr-old $\mathrm{CH}-\mathrm{B}$ patient who demonstrates the serological profile of a number of anti-HBe negative ASC patients (Fig. $6 \mathrm{~A}$ ). This patient was observed over a 4-yr period and exhibited a relatively low titer anti-HBc response (i.e., $P / N$ $<10$ ) predominated by $\operatorname{IgG}_{1}$ subclass antibodies with a deficit in production of anti-HBc antibodies of the $\mathrm{IgG}_{3}$ subclass, and no evidence of an immune response to the other HBV structural proteins. This patient expressed high levels of serum $\mathrm{HBV}$ DNA, and remained $\mathrm{HBsAg}$ - and $\mathrm{HBeAg}$-positive without serological or histological evidence of liver disease during the entire observation period (Fig. $6 \mathrm{~A}$ ) . Patient T.Y. is a 21 -yr-old CH-B patient who exhibits a serological profile representative of anti$\mathrm{HBe}$-positive ASC patients (Fig. $6 \mathrm{~B}$ ). The level of anti-HBc antibody production in this patient was significantly higher than that of patient K.K., but like K.K. the anti-HBc response was predominated by $\operatorname{IgG}_{1}$ subclass anti-HBc antibodies with a deficit in the production of anti-HBc antibodies of the $\mathrm{IgG}_{3}$ subclass. The anti-HBe antibody response of patient T.Y. was characterized by a lower titer as compared to CAH patients, and by minimal production of anti-HBe antibodies of the $\mathrm{IgG}_{3}$ subclass. The production of anti-envelope antibodies (measured as HBsAg/IC's) was similar in patient T.Y. and in CAH patients, whereas anti-HBe negative ASC patients rarely produce anti-envelope antibodies. It is important to note that anti$\mathrm{HBe}$ and anti-envelope antibodies were not detected in patient T.Y. by the commercial assay methods (Fig. $6 \mathrm{~B}, t o p$ ). Patient T.Y. was observed for 5 yrs and demonstrated no evidence of liver disease and remained HBV DNA positive. The third serological pattern is represented by 19-year-old T.M., diagnosed with $\mathrm{CAH}$, who demonstrated three episodes of liver disease during three years, and spontaneously cleared HBV-DNA and lost $\mathrm{HBeAg}$ (Fig. 7). Of course, not all CAH patients incur such frequent acute exacerbations of liver disease, nor do they

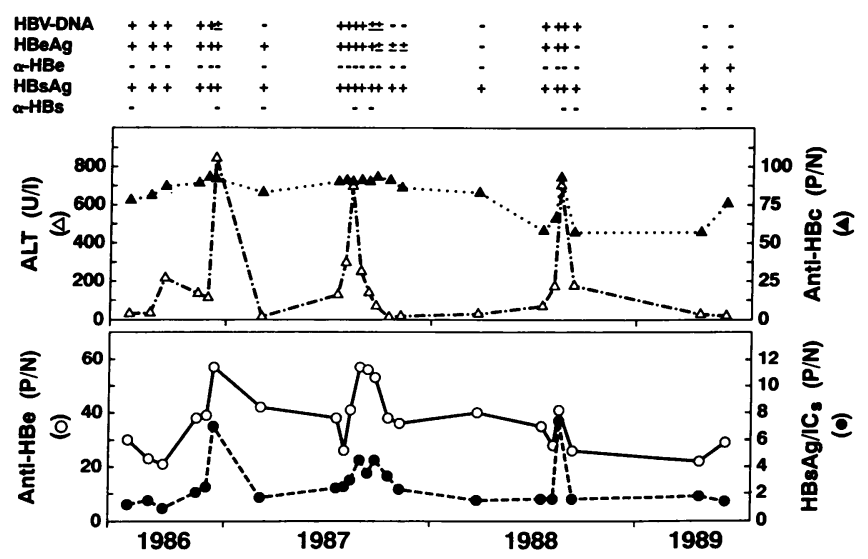

Figure 7. Serologic profile of a representative symptomatic CH-B patient. Serum samples were collected periodically from 1986 to 1989 from 19-yr-old T.M., a CAH patient, and analyzed as described in Fig. 6, except that sera were diluted 1:25,600 for the anti-HBc EIA. 
spontaneously clear HBV as T.M. did. Humoral immune responses specific for $\mathrm{HBcAg}, \mathrm{HBeAg}$, and $\mathrm{HBsAg}$ were present and antibody levels increased in parallel with ALT elevations. The anti-HBc and anti-HBe antibody responses were characterized by $\operatorname{IgG}_{1}$ and $\operatorname{IgG}_{3}$ subclass antibody production. Note that the anti-HBe response was positive before the first ALT elevation and the anti-envelope response became detectable during the first ALT elevation using the more sensitive assays, whereas, an anti-HBe antibody seroconversion was not detected by the commercial anti-HBe assay until after the third ALT elevation and loss of $\mathrm{HBeAg}$ from serum, and anti-HBs antibodies were never detected by the commercial assay (Fig. 7, top).

\section{Discussion}

The serology and natural history of $\mathrm{HBeAg}$-positive $\mathrm{CH}-\mathrm{B}$ infection have been established primarily through the use of commercial immunoassays to measure HBV structural antigens and their respective antibodies. However, the commercial assays were not designed to detect serum antibodies in an excess of circulating antigens, and usually detect anti-HBs and anti-HBe antibodies only after the respective antigens have been cleared from the serum. Therefore, it is not surprising that $\mathrm{CH}$-B infection has been serologically characterized by the presence of circulating antigens ( $\mathrm{HBsAg}$, pre-SAg, $\mathrm{HBeAg}$ ), and by the absence of serum antibodies regardless of the clinical status of chronic infection. This study, using sensitive immunoassays capable of detecting antibody in the presence of excess serum antigen, reexamined the serology of $\mathrm{CH}-\mathrm{B}$ infection and defined three novel serologic profiles in the context of active viral replication (Table $\mathrm{I}$ ). It is notable that virtually all $\mathrm{CH}-\mathrm{B}$ patients with liver disease (profile III) and $55.6 \%$ of ASC patients without disease (profile II) demonstrate ongoing humoral immune responses including anti-HBe and anti-envelope antibody production. Only profile I, representative of $44.4 \%$ of ASC patients, is characterized by the absence of anti-HBe and anti-envelope antibody production, although this is the serology currently widely believed to characterize all $\mathrm{HBeAg}$-positive $\mathrm{CH}-\mathrm{B}$ patients. However, another recent study has also indicated a greater incidence of anti-HBe antibody production in $\mathrm{HBeAg}$-positive $\mathrm{CH}-\mathrm{B}$ patients (6). Similarly, recent studies using a variety of $\mathrm{HBsAg-specific} \mathrm{IC} \mathrm{assays} \mathrm{indicate} \mathrm{that}$
HBsAg can persist in the circulation in the form of $\mathrm{HBsAg}$ anti-HBs IC's (21-25). Furthermore, it was previously shown that HBsAg-specific IC levels were higher in $\mathrm{CAH}$ patients than in ASC or acute HBV patients (22). In light of these new serological findings, the concept of a relatively non-overlapping seroconversion from $\mathrm{HBeAg}$-positive to anti- $\mathrm{HBe}$-positive status during $\mathrm{CH}-\mathrm{B}$ infection must be amended. Herein, it was demonstrated that anti-HBe seroconversion can occur many years (at least 6.5) before the loss of $\mathrm{HBeAg}$ or liver injury. Similarly, anti-envelope antibodies may co-exist with virions and subviral $\mathrm{HBsAg}$ particles for many years before viral clearance and loss of HBsAg. Therefore, the ability to detect anti$\mathrm{HBe}$ and anti-envelope antibody seroconversion events early will be useful as a means of monitoring the onset of underlying cellular immune responses (i.e., Th cell sensitization), whereas current antibody detection methods merely confirm antigen clearance after the fact. Furthermore, early detection of anti$\mathrm{HBe}$ antibody production especially of the $\mathrm{IgG}_{3}$ subclass may have predictive value in alerting physicians to the possibility of future liver injury. Similarly, anti-HBe positive ASC patients may benefit from immunomodulation therapy [i.e., IFN], whereas, anti-HBe-negative ASC patients may not.

Although we have not directly examined $\mathrm{HBe} / \mathrm{HBcAg}$-specific $\mathrm{T}$ cells in $\mathrm{CH}-\mathrm{B}$ patients, the specificity and source of $\mathrm{T}$ cell helper function for anti-HBc, anti-HBe, and anti-envelope antibody production can be inferred from a complete serologic analysis. Because anti-HBc production can occur via a $\mathrm{T}$ cellindependent pathway and $\mathrm{HBcAg}$ and $\mathrm{HBeAg}$ are cross-reactive at the Th cell level $(10,20)$, the production of low titer and predominantly $\mathrm{IgG}_{1}$ subclass anti-HBc antibodies in the absence of anti-HBe antibody production (profile I) most likely requires little or no $\mathrm{HBe} / \mathrm{HBcAg}$-specific Th cell function. Similarly, anti-HBe negative ASC patients produce minimal or no anti-envelope antibodies. This subset of ASC patients apparently lacks sufficient Th cell function to produce antibodies to $\mathrm{T}$ cell-dependent $\mathrm{HBV}$ antigens. In contrast, the serological evidence indicates that the anti-HBe positive subset of ASC patients (profile II) possesses adequate $\mathrm{HBeAg}$-specific Th cell function to produce higher titer anti-HBc as well as anti-HBe antibodies. Additionally, a high proportion of these ASC patients also produce anti-envelope antibody. Therefore, anti$\mathrm{HBe}$ positive ASC patients apparently possess sufficient $\mathrm{Th}$ cell function to produce high titer anti-HBc, anti-HBe, and anti-en-

Table I. Summary of the Serologic Profiles of CH-B Infection and Proposed Roles of HBeAg-specific Th Cells

\begin{tabular}{|c|c|c|c|c|}
\hline Clinical diagnosis & $\begin{array}{l}\text { Serologic } \\
\text { profile }\end{array}$ & HBeAg-Th & Functions & Liver disease \\
\hline ASC & 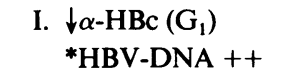 & 0 & - & 0 \\
\hline ASC & II. $\begin{array}{l}\uparrow \alpha-\operatorname{HBc}\left(G_{1}\right) \\
\alpha-\operatorname{HBe}\left(G_{1}\right) \\
\alpha-H B e n v \\
\text { HBV-DNA }++\end{array}$ & $\mathrm{Th}_{2}$-like & $\uparrow$ Antibody production & 0 \\
\hline $\begin{array}{l}\mathrm{CAH} \\
\mathrm{CPH}\end{array}$ & III. $\begin{aligned} & \uparrow \alpha-\operatorname{HBc}\left(\mathrm{G}_{1}+\mathrm{G}_{3}\right) \\
& \uparrow \alpha-\operatorname{HBe}\left(\mathrm{G}_{1}+\mathrm{G}_{3}\right) \\
& \uparrow \alpha-\mathrm{HBenv} \\
& \text { HBV-DNA + to } 0\end{aligned}$ & $\begin{array}{c}\mathrm{Th}_{1} \text {-like } \\
+ \\
\mathrm{Th}_{2} \text {-like }\end{array}$ & $\begin{array}{l}\uparrow \text { Inflammatory response } \\
\alpha-\mathrm{HBc} / \mathrm{HBe} \rightarrow \mathrm{G}_{3} ?\end{array}$ & ++ to \pm \\
\hline
\end{tabular}

* HBV-DNA $++>1,000 \mathrm{pg} / \mathrm{ml} .+5-1,000 \mathrm{pg} / \mathrm{ml} .0<5 \mathrm{pg} / \mathrm{ml}$ 
velope antibodies as do CAH patients, yet these cellular responses are not sufficient to mediate or play a significant role in liver injury. What serological evidence distinguishes between the Th cell responses of anti-HBe positive ASC patients without liver disease (profile II) and CAH patients with liver disease (profile III)? In this regard, anti-HBc and anti-HBe antibody titers are significantly higher in $\mathrm{CAH}$ patients as compared to anti-HBe positive ASC patients, especially during acute exacerbations of liver injury. A possibly more significant difference can be noted in the IgG subclass distribution of anti$\mathrm{HBc}$ and anti-HBe antibodies produced by ASC versus $\mathrm{CAH}$ patients. The ASC patients of both subgroups demonstrate a defect in the production of anti-HBc antibodies of the $\mathrm{IgG}_{3}$ subclass, and anti-HBe positive ASC patients also produce low levels of $\mathrm{IgG}_{3}$ subclass anti-HBe antibodies, as compared to $\mathrm{CAH}$ patients in which the $\mathrm{IgG}_{3}$ subclass predominates along with $\operatorname{IgG}_{1}$. The co-production of $\operatorname{IgG}_{1}$ and $\operatorname{IgG}_{3}$ subclass antibodies characterize the normal human humoral immune response to protein antigens and especially to protein antigens of viral origin, including $\mathrm{HBV}$ antigens (27-29). The association of the $\mathrm{IgG}_{3}$ subclass with viral infection and the identification of IFN response elements in the $\mathrm{C} \gamma 3$ gene (30) suggest that IFN may enhance human $\mathrm{IgG}_{3}$ subclass antibody production to $\mathrm{HBeAg}$ and $\mathrm{HBcAg}$. The ability of Th subsets to influence the IgG subclass of the antibodies produced via the assortment of lymphokines secreted (i.e., $\mathrm{Th}_{1}, \mathrm{IL}-2$, and $\gamma$-IFN; $\mathrm{Th}_{2}, \mathrm{IL}-4$, and IL-5) is well established in the murine system (31) and is becoming apparent in humans as well (32). In the murine system, we have observed that certain $\mathrm{HBeAg}$-specific $\mathrm{T}$ cell site-MHC combinations preferentially elicit either a $\mathrm{Th}_{1}$-like (proliferation) or a $\mathrm{Th}_{2}$-like (antibody) response (unpublished observation). We propose that the production of low titer and $\mathrm{IgG}_{3}$ subclass-deficient anti-HBc and anti-HBe responses in ASC versus $\mathrm{CAH}$ patients reflects differential engagement of Th subsets among these patient groups. The serologic profile (II) and absence of liver disease in anti-HBe positive ASC patients is consistent with an exclusive $\mathrm{Th}_{2}$-like response. Alternatively, the serology (III) and evidence of immune-mediated cytotoxic responses in CAH patients suggest a $\mathrm{Th}_{1}$-like or combined $\mathrm{Th}_{1}-\mathrm{Th}_{2}$-like response. The $\mathrm{Th}_{1}$ subset mediates an inflammatory response and is characterized by significant $T$ cell proliferation and IL-2 production, delayed-type hypersensitivity reactivity, and the varied effects of $\boldsymbol{\gamma}$-IFN production (i.e., enhanced MHC expression, direct anti-viral effects, suppression of murine $\mathrm{IgE}$ and $\mathrm{IgG}_{1}$, and enhancement of murine $\operatorname{IgG}_{2 \mathrm{a}}$ [33]). Because of the low level expression of MHC class I molecules on normal hepatocytes, $\mathrm{Th}_{1}$-derived $\gamma$-IFN may be required to enhance the level of MHC class I sufficiently to allow for $\mathrm{CD}^{+} \mathrm{T}$ cell-mediated CTL recognition of infected hepatocytes (34). A recent study of intrahepatic $\mathrm{T}$ cells in $\mathrm{CAH}$ patients revealed the presence of $\mathrm{HBe} / \mathrm{HBcAg}$-specific $\mathrm{CD} 4^{+}$ and $\mathrm{CD}^{+} \mathrm{T}$ cells, and cloned $\mathrm{CD} 4^{+} \mathrm{T}$ cells secreted IL-2, $\gamma$-IFN, and TNF $(35,36)$, which is consistent with a $\operatorname{Th}_{1}$ phenotype. The direct anti-viral effects of $\gamma$-IFN may also be important in maintaining lower levels of $\mathrm{HBV}$ replication even in the absence of direct cytolytic activity, which seems to occur only sporadically during $\mathrm{CAH}$ infection.

Both anti-HBe-positive ASC and CAH patients produce anti-envelope antibody. However, anti-envelope antibody production by $\mathrm{CH}-\mathrm{B}$ infected patients correlates with anti-HBe production, and does not appear to be mediated by envelopespecific Th cells inasmuch as the decline in anti-envelope anti- body parallels the decline in HBV-DNA and HBeAg concentrations at a time when serum envelope antigen concentrations remain elevated (Fig. $5 B$ ). This observation together with the fact that $\mathrm{HBe} / \mathrm{HBcAg}$-specific $\mathrm{Th}$ cells have been shown to elicit anti-envelope antibody production (26), suggest that HBeAg-specific Th cells may mediate anti-envelope antibody production in $\mathrm{CH}-\mathrm{B}$ infection. This hypothesis is consistent with a number of recent reports that have demonstrated $\mathrm{HBe}$ / $\mathrm{HBcAg}$-specific $\mathrm{T}$ cell proliferative responses but not $\mathrm{HBsAg}$ or pre-S-specific $\mathrm{T}$ cell proliferation in $\mathrm{CH}-\mathrm{B}$ patients (37-40). Furthermore, increasing levels of $\mathrm{HBe} / \mathrm{HBcAg}$-specific $\mathrm{T}$ cell proliferation were reported to occur just before acute exacerbations of liver injury (37), which correlates precisely with the timing of increases in anti-HBc, anti-HBe, and anti-envelope antibody levels in $\mathrm{CAH}$ patients (Fig. $5 \mathrm{~A}$ and 7). The serologic studies indicate that $\mathrm{HBeAg}$ and not the envelope antigens appears to be the focus of $\mathrm{Th}$ cell recognition in the context of $\mathrm{CH}-\mathrm{B}$ infection, and that $\mathrm{HBeAg}$-specific Th cells play a predominant immunoregulatory role in the immune response to multiple HBV antigens. This may, in part, explain the emergence of $\mathrm{HBV}$ variants which cannot produce $\mathrm{HBeAg}$ (i.e., pre-core mutants) during the course of $\mathrm{CH}-\mathrm{B}$ infection (4143). Such variants may represent escape mutants immunoselected by virtue of greater survival in the milieu of a long-term immune response predominantly regulated by $\mathrm{HBeAg-specific}$ Th cells (44).

The vast majority of the Japanese patients enrolled in this study were infected in the neonatal or perinatal period by $\mathrm{HBeAg}$-positive $\mathrm{CH}-\mathrm{B}$ infected mothers, and subsequently became $\mathrm{CH}-\mathrm{B}$ carriers. Evidence from an $\mathrm{HBeAg}$-expressing transgenic murine model and human epidemiological observations suggest that the $\mathrm{HBeAg}$ can traverse the placenta, and in utero exposure to $\mathrm{HBeAg}$ may elicit immunologic $\mathrm{T}$ cell tolerance, which may predispose to chronicity (45). The recent report that neonatal infections with an $\mathrm{HBeAg-negative} \mathrm{variant}$ of $\mathrm{HBV}$ resulted in acute fulminant hepatitis rather than chronic infection supports the role of $\mathrm{HBeAg}$-specific tolerance in chronic infection of the neonate (46). The observation reported herein, that most $\mathrm{CH}-\mathrm{B}$ patients possess anti-HBe as well $\mathrm{HBeAg}$ in serum, suggests that $\mathrm{HBeAg} /$ anti-HBe IC's rather than free $\mathrm{HBeAg}$ may be transported across the placenta. This is consistent with a report that virtually all the $\mathrm{HBeAg}$ in the cord blood of infants born to $\mathrm{CH}-\mathrm{B}$ infected mothers was immune-complexed (47). The correlation between anti-HBe production and the degree of liver disease among $\mathrm{CH}-\mathrm{B}$ patients is consistent with the hypothesis that $\mathrm{T}$ cell tolerance to $\mathrm{HBeAg}$ leads to chronicity, and suggests that $\mathrm{HBeAg}$-specific $\mathrm{T}$ cells emerging from the tolerant state mediate viral clearance and the serologic responses characterized in profiles II and III (Table I). Do the three serologic profiles represent transitional phases of $\mathrm{CH}-\mathrm{B}$ infection, beginning with asymptomatic neonatal infection and progressing to $\mathrm{CAH}$, or is there little overlap? Long-term follow-up studies of patients exhibiting profiles I and II using these sensitive serologic assays will be required to answer this question. Another open question is why some $\mathrm{CAH}$ patients spontaneously clear HBV infection and others do not. All CAH patients exhibit a type III serologic profile, with no apparent serological distinction between them. Therefore, an immune response competent to elicit antibody production to $\mathrm{HBcAg}, \mathrm{HBeAg}$, and the envelope proteins of $\mathrm{HBV}$, and sufficient to mediate liver injury may be necessary but not quantitatively or qualitatively sufficient to completely clear $\mathrm{HBV}$ in the 
context of all $\mathrm{CH}-\mathrm{B}$ infections. The $\mathrm{HBeAg}$ transgenic murine model provides evidence that the degree of $\mathrm{HBeAg}$-specific $\mathrm{Th}$ cell tolerance can be variable, depending on the MHC genotype of the strain (48). Furthermore, murine $T h_{1}$ and $T h_{2}$ subsets appear to differ with respect to tolerance induction (49, 50 ). Comparable genetic variability among $\mathrm{CH}-\mathrm{B}$ patients infected at birth may explain differences in serologic profiles and in spontaneous HBV clearance rates.

In summary, the use of more sensitive serologic assays has revealed that substantial immune responsiveness can occur during $\mathrm{CH}-\mathrm{B}$ infection, and three representative serologic profiles were described. Additional serologic profiles may emerge as more heterogeneous populations of $\mathrm{CH}-\mathrm{B}$ patients are examined. However, the serologic profiles described in this study are much more consistent with the concept of immune-mediated liver injury and $\mathrm{HBV}$ clearance in $\mathrm{CH}-\mathrm{B}$ infection than is the conventional serology, which suggests that $\mathrm{CH}-\mathrm{B}$ patients are immunologically nonresponsive despite ongoing liver disease.

\section{Acknowledgments}

The authors thank Professor M. Mayumi for monoclonal reagents, Drs. D. Peterson for recombinant pre $(\mathrm{S} 1+\mathrm{S} 2)$ polypeptide, $\mathrm{F}$. Schödel for rHBcAg, and G. Bitter for rHBsAg, and Drs. K. Kurai, K. Yasuda, Y. Ikeda, and S. Hayashi (Tokyo University) for providing patient sera, and Ms. Rene Lang for preparation of the manuscript.

This work was supported by National Institutes of Health Grant AI-20720. Toshiyuki Maruyama was supported by a grant from the Japanese government. This is publication No. 7449-MB from The Scripps Research Institute.

\section{References}

1. Beasley, R. P., L.-Y. Hwang, C.-C., Lin, and C.-S. Chien. 1981. Hepatocellular carcinoma and hepatitis B virus. Lancet. ii:1129-1133.

2. Alberti, A., A. Trevisan, G. Fattovich, and G. Realdi. 1984. The role of hepatitis B virus replication and hepatocyte membrane expression in the pathogenesis of HBV-related hepatic damage. In Advances in Hepatitis Research. F. V. Chisari, editor. Masson Publishing USA, Inc., New York. 134-143.

3. Hoofnagle, J. H., G. M. Dusheiko, L. B. Seeff, E. A. Jones, J. G. Waggoner, and Z. B. Bales. 1981. Seroconversion from hepatitis B e antigen to antibody in chronic type B hepatitis. Ann. Intern. Med. 94:744-748.

4. Realdi, G., A. Alberti, M. Rugge, F. Bortolotti, A. M. Rigoli, F. Tremolada, and A. Ruol. 1980. Seroconversion from hepatitis $B$ e antigen to anti-HB $\mathrm{H}_{e}$ in chronic hepatitis B virus infection. Gastroenterology. 79:195-199.

5. Maruyama, T., G. B. Thornton, S. Iino, K. Kurokawa, and D. R. Milich. 1992. Use of anti-peptide antibodies for the design of antigen-specific immune complex assays. J. Immunol. Methods. 155:65-75.

6. Sällberg, M., H. Norder, G. Lindh, and L. O. Magnius. 1991. IgG subclasses in circulating immune complexes with hepatitis $B$ e antigen in chronic hepatitis. Clin. Exp. Immunol. 84:116-121.

7. Langley, K. E., K. M. Egan, J. M. Barendt, C. G. Parker, and G. A. Bitter. 1988. Characterization of purified hepatitis B surface antigen containing pre-S(2) epitopes expressed in Saccharomyces cerevisiae. Gene Amst. 67:229-245.

8. Schödel, F., T. Weimer, H. Will, and D. R. Milich. 1990. Recombinant HBV core particles carrying immunodominant B-cell epitopes of the HBV pre-S 2 region. In Vaccines 90 . F. Brown, R. M. Chanock, H. S. Ginsberg, and R. A. Lerner, editors. Cold Spring Harbor Laboratory, Cold Spring Harbor, NY 193198.

9. Stahl, S., P. Mackay, M. Magazin, S. A. Bruce, and K. Murray. 1982. Hepatitis B virus core antigen: synthesis in Escherichia coli and application in diagnosis. Proc. Natl. Acad. Sci. USA. 79:1606-1610.

10. Milich, D. R., A. McLachlan, S. Stahl, P. Wingfield, G. B. Thornton, J. L. Hughes, and J. E. Jones. 1988. Comparative immunogenicity of hepatitis B virus core and e antigens. J. Immunol. 141:3617-3624.

11. Delos, S., M. T. Villar, P. HU, and D. Peterson. 1991. Cloning, expression, isolation and characterization of the pre-S domains of hepatitis B surface antigen, devoid of the S protein. Biochem. J. 276:411-416.

12. Takahashi, K., A. Machida, G. Funatsu, M. Nomura, S. Usuda, S. Aoyagi, K. Tachibana, H. Miyamoto, M. Imai, T. Nakamura, Y. Miyakawa, and M.
Mayumi. 1983. Immunochemical structure of hepatitis B e antigen in the serum. J. Immunol. 130:2903-2907.

13. Imai, M., T. Nomura, and T. Gotanda, T. Sano, K. Tachibana, H. Miyamoto, K. Takahashi, S. Toyama, Y. Miyakawa, and M. Mayumi. 1982. Demonstration of two distinct antigenic determinants on hepatitis $\mathrm{B}$ e antigen by monoclonal antibodies. J. Immunol. 128:69-72.

14. Takahashi, K., S. Kishimoto, K. Ohori, H. Yoshizawa, A. Machida, H. Ohnuma, F. Tsuda, E. Munekata, Y. Miyakawa, and M. Mayumi. 1991. Molecular heterogeneity of e antigen polypeptides in sera from carriers of hepatitis B virus. J. Immunol. 147:3156-3160.

15. Machida, A., S. Kishimoto, H. Ohnuma, K. Baba, Y. Ito, H. Miyamoto, G. Funatsu, K. Oda, S. Usuda, S. Togami, et al. 1984. A polypeptide containing 55 amino acid residues coded by the pre-S region of hepatitis $B$ virus deoxyribonucleic acid bears the receptor for polymerized human as well as chimpanzee albumins. Gastroenterology. 86:910-918.

16. Alexander, H., and R. A. Lerner. 1984. Chemically synthesized peptide analogues of the hepatitis B surface antigen. In Advances in Hepatitis Research. F. V. Chisari, editor. Masson Publishing USA, Inc., New York. 223-229.

17. Laemmli, U. K. 1970. Cleavage of structural proteins during the assembly of the head of bacteriophage T4. Nature (Lond.). 227:680-685.

18. Leevy, C. M., H. Popper, and S. Sherlock. 1976. Diseases of the liver and biliary tract: standardization of nomenclature, diagnostic criteria and diagnostic methodology. In Fogarty International Center Proceedings No. 22. DHEW Publication No. 76-725 (NIH). U. S. Government Printing Office Washington, DC. $1-24$.

19. Lieberman, H. M., D. R. LaBrecque, M. C. Kew, S. J. Hadziyannis, and D. A. Shafritz. 1983. Detection of hepatitis B virus DNA directly in human serum by a simplified molecular hybridization test: comparison to $\mathrm{HBeAg} /$ anti-HBe status in HBsAg carriers. Hepatology. 3:285-291.

20. Milich, D. R., and A. McLachlan. 1986. The nucleocapsid of the hepatitis $B$ virus is both a $T$ cell-independent and a $T$ cell-dependent antigen. Science (Wash. DC). 234:1398-1401.

21. Anh-Tuan, N., and E. Novák. 1981. Hepatitis B surface antigen circulating immune complexes ( $\mathrm{HBsAg-CICs)}$ in patients with hepatitis B and asymptomatic HBsAg carriers. Clin. Exp. Immunol. 43:246-253.

22. Brown, S. E., M. W. Steward, L. Viola, C. R. Howard, and I. M. MurrayLyon. 1983. Chronic liver disease: the detection and characterization of circulating immune complexes. Immunology. 49:673-683.

23. Rath, S., and M. E. Devey. 1988. IgG subclass composition of antibodies to $\mathrm{HBsAg}$ in circulating immune complexes from patients with hepatitis B virus infections. Clin. Exp. Immunol. 72:164-167.

24. Thomas, H. C., D. De Villiers, B. Potter, H. Hodgson, S. Jain, D. P. Jewell, and S. Sherlock. 1978. Immune complexes in acute and chronic liver disease. Clin. Exp. Immunol. 31:150-157.

25. Pernice, W., C. P. Sodomann, G. Lüben, F. R. Seiler, and H. H. Sedlacek. 1979. Antigen-specific detection of HBsAg-containing immune complexes in the course of hepatitis B virus infection. Clin. Exp. Immunol. 37:376-380.

26. Milich, D. R., A. McLachlan, G. B. Thornton, and J. L. Hughes. 1987. A synthetic $T$ cell site primes antibody production to both the nucleocapsid and envelope of the hepatitis B virus. Nature (Lond.). 329:547-549.

27. Beck, O. E. 1981. Distribution of virus antibody activity among human IgG subclasses. Clin. Exp. Immunol. 43:626-632.

28. Sällberg, M., H. Norder, A. Linde, and L. O. Magnius. 1988. Subclass pattern of anti-HBc IgG in chronic hepatitis $\mathrm{B}$ : relation to $\mathrm{HBeAg} /$ anti-HBe and HBV-DNA. In Viral Hepatitis and Liver Disease. A. J. Zuckerman, editor. Alan R. Liss, New York. 244-247.

29. Skvaril, F., and H. Joller-Jemelka. 1984. IgG subclasses of anti-HBs antibodies in vaccinated and non-vaccinated individuals and in anti-HBs immunoglobulin preparations. Int. Arch. Allergy Appl. Immunol. 73:330-337.

30. Mills, F. C., J. S. Brooker, and R. D. Camerini-Otero. 1990. Sequences of human immunoglobulin switch regions: implication for recombination and transcription. Nucleic Acids. Res. 18:7305-7316.

31. Mosmann, T. R., and R. L. Coffman. 1987. Two types of mouse helper T-cell clone. Immunol. Today. 8:223-227.

32. Romagnani, $S$. 1991. Human $T_{H} 1$ and $T_{H} 2$ subsets: doubt no more. Immunol. Today. 12:256-257.

33. Snapper, C. M., and W. E. Paul. 1987. Interferon- $\gamma$ and B cell stimulation factor 1 reciprocally regulate Ig isotype production. Science (Wash. DC). 236:944-947.

34. Peters, M., G. Davis, J. S. Dooley, and J. H. Hoofnagle. 1986. The interferon system in acute and chronic viral hepatitis. Prog. Liver Dis. 8:453-467.

35. Ferrari, C., A. Penna, T. Giuberti, M. J. Tong, E. Ribera, F. Ficcadori, and F. V. Chisari. 1987. Intrahepatic nucleocapsid antigen-specific $T$ cells in chronic active hepatitis B. J. Immunol. 139:2050-2058.

36. Ferrari, C., M. U. Mondelli, A. Penna, F. Ficcadori, and F. V. Chisari. 1987. Functional characterization of cloned intrahepatic, hepatitis B virus nucleoprotein-specific helper T cell lines. J. Immunol. 139:539-544.

37. Tsai, S. L., P. J. Chen, M. Y. Lai, P. M. Yang, J. L. Sung, J. H. Huang, L. H. Hwang, T. H. Chang, and D. S. Chen. 1992. Acute exacerbations of chronic 
type B hepatitis are accompanied by increased $T$ cell responses to hepatitis B core and e antigens. J. Clin. Invest. 89:87-96.

38. Ferrari, C., A. Penna, P. Sansoni, T. Giuberti, T. M. Neri, F. V. Chisari, and F. Ficcadori. 1986. Selective sensitization of peripheral blood T lymphocytes to hepatitis B core antigen in patients with chronic active hepatitis type B. Clin. Exp. Immunol. 67:497-506.

39. Vento, S., J. E. Hegarty, A. Alberti, C. J. O'Brien, G. J. M. Alexander, A. L. W. F. Eddleston, and R. Williams. 1985. T lymphocyte sensitization to $\mathrm{HBcAg}$ and $\mathrm{T}$ cell-mediated unresponsiveness to $\mathrm{HBsAg}$ in hepatitis B virus-related chronic liver disease. Hepatology. 5:192-197.

40. Inoue, M., S. Kakumu, K. Yoshioka, Y. Tsutsumi, T. Wakita, and M. Arao. 1989. Hepatitis B core antigen-specific IFN- $\gamma$ production of peripheral blood mono-nuclear cells in patients with chronic hepatitis B virus infection. $J$. Immunol. 142:4006-4011.

41. Brunetto, M., M. Stemler, F. Schödel, H. Will, M. Ottobrelli, M. Rizzetto, $\mathrm{G}$. Verme, and F. Bonino. 1989. Identification of HBV variants which cannot produce precore derived $\mathrm{HBeAg}$ and may be responsible for severe hepatitis. $J$. Gastroenterol. Hepatol. 21:151-154.

42. Carman, W. F., M. R. Jacyna, S. Hadziyannis, P. Karayiannis, M. J. McGarvey, A. Makris, and H. C. Thomas. 1989. Mutation preventing formation of hepatitis B e antigen in patients with chronic hepatitis B infection. Lancet. ii: $588-590$.

43. Okamoto, H., S. Yotsumoto, Y. Akahane, T. Yamanaka, Y. Miyazaki, Y. Sugai, F. Tsuda, T. Tanaka, Y. Miyakawa, and M. Mayumi. 1990. Hepatitis B viruses with precore region defects prevail in persistently infected hosts along with seroconversion to the antibody against e antigen. J. Virol. 64:1298-1303.

44. Milich, D. R. 1991. Immune response to hepatitis B virus proteins: relevance of the murine model. Semin. Liver Dis. 11:93-112.

45. Milich, D. R., J. E. Jones, J. L. Hughes, J. Price, A. K. Raney, and A. McLachlan. 1990. Is a function of the secreted hepatitis B e antigen to induce immunologic tolerance in utero? Proc. Natl. Acad. Sci. USA. 87:6599-6603.

46. Terazawa, S., M. Kojima, T. Yamanaka, S. Yotsumoto, H. Okamoto, F. Tsuda, Y. Miyakawa, and M. Mayumi. 1991. Hepatitis B virus mutants with precore region defects in two babies with fulminant hepatitis and their mothers positive for antibody to hepatitis B e antigen. Pediatr. Res. 29:5-9.

47. Arakawa, K., F. Tsuda, K. Takahashi, I. Ise, S. Naito, E. Kosugi, Y. Miyakawa, and M. Mayumi. 1982. Maternofetal transmission of IgG-bound hepatitis B e antigen. Pediatr. Res. 16:247-250.

48. Milich, D. R., A. McLachlan, A. K. Raney, R. Houghten, G. B. Thornton, T. Maruyama, J. L. Hughes, and J. E. Jones. 1991. Autoantibody production in hepatitis $B$ e antigen transgenic mice elicited with a self $T$-cell peptide and inhibited with nonself peptides. Proc. Natl. Acad. Sci. USA. 88:4348-4352.

49. De Wit, D., M. Van Mechelen, M. Ryelandt, A. C. Figueiredo, D. Abramowicz, M. Goldman, H. Bazin, J. Urbain, and O. Leo. 1992. The injection of deaggregated gamma globulins in adult mice induces antigen-specific unresponsiveness of T helper type 1 but not type 2 lymphocytes. J. Exp. Med. 175:9-15.

50. Burstein, H., C. A. Shea, and A. K. Abbas. 1992. Aqueous antigens induce in vivo tolerance selectively in IL-2- and IFN- $\gamma$-producing (Th1) cells. $J$. Immunol. 148:3687-3691. 